\title{
ДИДАКТИЧНІ АСПЕКТИ ВИКЛАДАННЯ МЕДИЧНОЇ ФІЗИКИ У ВИЩОМУ МЕДИЧНОМУ НАВЧАЛЬНОМУ ЗАКЛАДІ
}

\section{Horbachevsky Ternopil National Medical University \\ DIDACTIC ASPECTS OF TEACHING MEDICAL PHYSICS IN MEDICAL SCHOOL}

\begin{abstract}
Анотація. Важливою складовою базової підготовки майбутнього медика залишається медична та біологічна фізика, оскільки саме у процесі вивчення цього предмета здійснюється розвиток природничо-наукового мислення студентів. Медична фізика вивчається на першому курсі вищого медичного закладу. На початку вивчення матеріалу студенти повинні володіти фундаментальними теоріями з фізики, які розглядалися у середніх навчальних закладах. Сформована у них наукова та фізична картина світу за шкільні роки під час вивчення природничих наук у виші лише розширюється та поглиблюється. Таким чином реалізується принцип наступності вивчення фізики у системі неперервної освіти. Специфіка дидактичного підходу до вивчення фізики в медичному університеті значною мірою зумовлена тим, що для спеціаліста-фізика основним є фізична суть явищ природи, а для фахівця-медика об’єктом дослідження є людина. Для фахівців медичної галузі фізика виступає як фундаментальна природничо-наукова дисципліна, і для них головним $€$ вміння використовувати знання фізики при розв’язанні фахових проблем. Викладачі кафедри підготували нову навчально-методичну літературу для дисциплін, які викладаються на кафедрі. У нових навчальних посібниках приділено багато уваги практичному аспекту можливого використання набутих знань у майбутній діяльності лікаря, відображено останні досягнення фізичної науки в галузі медичної діагностики та лікування. Однією з форм проведення практичних занять на кафедрі $є$ використання елементів проблемного навчання. Створення проблемних ситуацій активізує пізнавальну діяльність студентів на занятті. У професійній діяльності лікаря важливу роль відіграє вміння правильно діагностувати захворювання. В основі більшості діагностичних методів лежать фізичні закони, теорії, наукові факти, а також фізичні властивості об’єктів і закономірності перебігу фізичних явищ, тому виникає необхідність навчати майбутнього лікаря діагностичної діяльності уже на етапі вивчення медичної фізики. У цьому аспекті застосовуємо компетентнісний підхід, у рамках якого закладаються основи діагностичних компетенцій.
\end{abstract}

Ключові слова: медична фізика; проблемне навчання; компетентнісний підхід.

Abstract. An important component of basic training for a future physician is medical and biological physics, since the development of students' natural-scientific thinking is carried out during learning of this subject. Medical Physics is studied during the first year at the medical school. At the beginning of the learning, students have to know basic theories in Physics considered in secondary schools. The scientific and physical picture of the world formed during the learning of natural sciences at school and it is only expanding and deepening in the higher institutions. Therefore, the principle of continuity of learning Physics in the system of continuous education is realized. The peculiarity of the didactic approach to learning Physics at a medical university is mostly caused by the fact that the physical essence of the phenomena of nature is the basic for the physicist, and a man is the object of study for the medical practitioner. Physics acts as a fundamental natural science discipline for medical practitioners, and the main thing for them is the ability to use Physics to solve professional problems. The teachers of the Department have prepared new educational and methodical resources for the subjects taught in the department. Much attention is paid to the practical aspect of the possible use of the acquired knowledge in the future activity of the physician, and the latest achievements of physical science in the field of medical diagnostics and treatment are reflected in new manuals. The use of elements of problem learning is a form of practical training in the department. The creation of problem-solving situations activates the cognitive activity of students at the class. The ability to diagnose the disease correctly plays an important role in the physician's professional activity. Most diagnostic methods are based on physical laws, theories, scientific facts, as well as physical properties of objects and patterns of physical phenomena. So, there is a need to train a diagnostic activity of the future physician at the stage of learning medical physics. In this aspect, we apply a competence-based approach. The foundations of diagnostic competences are laid in it.

Key words: medical physics; problem training; competence-based approach.

() Б. М. Паласюк 
Вступ. Невід’ємною частиною сучасного етапу розвитку системи освіти стали технічні засоби навчання і нові технології та підходи у педагогіці. Великі обсяги навчального матеріалу і складність інформаційних потоків вимагають удосконалення систем навчання з метою підвищення ефективності навчального процесу. Педагогічна наука у цьому аспекті дає ряд рекомендацій, зокрема трансформувати навчальний процес у напрямі індивідуалізації освітньої взаємодії, навчання, формування творчого мислення і збільшення самостійної роботи студентів [3], використовувати найрізноманітніші евристичні методи, що здатні пробудити у студентів ініціативу, розкрити їх індивідуальні творчі здібності, розвинути логіку мислення у професійному напрямку, регулювати й інтенсифікувати процес творчого пошуку [2], формувати активну творчу особистість, що внутрішньо відповідає сучасній дійсності, механізму творчого мислення в період неперервної освіти [8].

У сучасних умовах невирішеною залишається проблема підготовки фахівців медичної галузі до створення і використання технологій нового покоління, набуття необхідних навичок застосування фундаментальних науково-природничих знань для розв’язання фахових проблем. Погоджуємося з С. М. Стадніченко [9] щодо необхідності доповнення матеріалу з біологічної і медичної фізики новітніми досягненнями природничих наук, без яких природничо-науковий світогляд лікаря-фахівця буде недостатньо сформованим. Науковець наголошує, що вдосконалення змісту курсу медичної фізики, обумовлене насиченням новими елементами знань та взаємозв'язками, дозволить не тільки підвищити престиж фізичної освіти через осучаснення ї̈ змісту, а й формувати у студентів природничо-наукове мислення, що сприятиме розумінню практики передових технологій діагностики та лікування.

Залишається невирішеною проблема відбору та структурування навчального матеріалу в курсі медичної фізики, який вивчається у медичних виших навчальних закладах. Суть цієї проблеми пов'язана з особливостями використання фізичних знань у фаховій діяльності. У медичній освіті пріоритетним $є$ не фізична суть явищ, а об’єктом дослідження виступає людина.

Окреслені проблеми визначають актуальність розробки науково-обгрунтованої сучасної методичної системи навчання медичної фізики у медичних університетах, яка б при належній фаховій спрямо- ваності забезпечувала фундаментальність фізикоматематичних дисциплін як базового складника природничо-наукової підготовки майбутніх лікарів та фармацевтів.

Мета статті - наукове обгрунтування теоретико-методичних засад вивчення медичної фізики у медичних університетах.

Теоретична частина. Фундаментальність освіти майбутнього лікаря забезпечується насамперед фундаментальними навчальними дисциплінами (загальноприродничими та професійно зорієнтованими), які, надаючи базові знання, формують основу професійної діяльності випускника. Базові професійні знання закладаються у загальноприродничих дисциплінах, тому одним із дійових засобів підвищення професійної підготовки фахівця є саме фундаменталізація професійних знань [10]. Разом 3 тим інноваційні процеси у сучасній вищій освіті вимагають від майбутніх лікарів не тільки володіння певним обсягом фундаментальних знань, а й розвитку різних видів мислення з метою формування компетентнісно-світоглядних професійних характеристик майбутнього фахівця, уміння змінювати та вдосконалювати свою діяльність на підставі самостійно здобутих знань. Важливою складовою базової підготовки майбутнього медика залишається медична та біологічна фізика, оскільки саме у процесі вивчення цього предмета здійснюється розвиток природничо-наукового мислення студентів.

Для розвитку природничо-наукового мислення важливим є не тільки зміст навчального матеріалу, а й методи його опрацювання, вивчення, засвоєння, узагальнення, а саме системно-діяльнісний підхід до навчання. Реалізація цих ідей здійснюється на лекціях та практичних заняттях. Викладачі кафедри медичної фізики діагностичного та лікувального обладнання на лекційних заняттях пропонують студентам проблемні питання у вигляді якісних задач, наочних ситуацій (із життєвого досвіду, з практики майбутньої професії, комп’ютерні моделі), демонстраційних дослідів тощо. При такому підході відбувається не тільки засвоєння нових знань, а й здійснюються різні операції мислення. Подання матеріалу у вигляді таблиць, структурно-логічної схеми, залучення нових інформаційних технологій дозволяє прискорити процес його розуміння.

Специфіка дидактичного підходу до вивчення фізики в медичному університеті значною мірою зумовлена тим, що для спеціаліста-фізика основним $є$ фізична суть явищ природи, а для фахівцямедика об’єкт дослідження - людина. Для фахівців 
медичної галузі фізика виступає як фундаментальна природничо-наукова дисципліна, і для них головним є вміння використовувати знання фізики при розв’язанні фахових проблем.

Рівень сформованості у студентів сучасного способу мислення значною мірою визначається засвоєнням фундаментальних фізичних явищ, понять, суджень, дій, теорій, законів, принципів. Медична фізика вивчається на першому курсі вищого медичного закладу. Згідно з навчальною програмою та змістом підручників [4], студенти на початку вивчення матеріалу повинні володіти фундаментальними теоріями з фізики та математичним апаратом, які розглядалися у середніх навчальних закладах. Сформована у них наукова та фізична картина світу за шкільні роки під час вивчення природничих наук у виші лише розширюється та поглиблюється. Таким чином реалізується принцип наступності вивчення фізики у системі неперервної освіти.

Принцип наступності має реалізуватися як у процесі вивчення природничонаукових дисциплін, так і спеціальних. Водночас у професійно-практичній підготовці цей принцип має бінарний характер. Спираючись на принцип фундаменталізації змісту освіти, наступність забезпечує систему інтегрованих знань, умінь та цінностей у ії розвитку: від актуалізації інтегративних зв’язків природничих дисциплін у загальноосвітній школі до забезпечення можливості інтеграції професійних знань та вмінь у післядипломній освіті та процесі підвищення кваліфікації. Тому забезпечення неперервності природничонаукової підготовки майбутніх лікарів вимагає використання інтегративного підходу для зв’ язку змісту із загальноосвітньою школою та післядипломною освітою.

Сучасного студента здебільшого цікавлять не сухі теоретичні знання, а бачення можливості практичного аспекту використання тих чи інших явищ та процесів, що вивчаються в даному курсі, і можливість використання сучасних комп’ютерних та інформаційних технологій для дослідження й аналізу цих явищ. У цьому аспекті викладачі кафедри підготували якісно нову навчально-методичну літературу для дисциплін, які викладаються на кафедрі. У нових навчальних посібниках приділено багато уваги практичному аспекту можливого використання набутих знань у майбутній діяльності лікаря, відображено останні досягнення фізичної науки в галузі медичної діагностики та лікування.

Однією з форм проведення практичних занять на кафедрі є використання елементів проблемного на- вчання. Створення проблемних ситуацій активізує пізнавальну діяльність студентів на занятті. Проблемно-орієнтоване навчання стимулює у студентів потребу вчитися, здобувати інформацію, необхідну для розв'язання проблеми. Проблема відрізняється від простого навчального завдання тим, що для їі розв’язання не можна застосувати стандартні методи [11]. Натрапляючи на нову, незрозумілу проблему, людське мислення відбувається за схемою: висування гіпотез, їх обгрунтування і перевірка, що і є необхідною умовою саме творчого мислення. Вирішення проблеми завжди пов’ язане з творчістю і спонукає до продуктивного мислення.

Проблема виступає стимулом, який спонукає визначити, яких знань, умінь чи навичок бракує, щоб її вирішити. Таким чином, метою проблемноорієнтованого навчання є не стільки сам результат розв’язання проблеми, як докладання інтелектуальних зусиль і підбір правильних методів для подолання проблеми. «Метою є шлях до мети», - так коротко і влучно характеризує сутність проблемноорієнтованого навчання А. Вебер [12].

Організація заняття з медичної фізики з використанням проблемних ситуацій здійснюється методами евристичної та пошукової бесіди. Студенти розв’язують проблему у присутності та з допомогою викладача. Під час проведення заняття викладач звертається до групи з пошуковими запитаннями. Демонструючи дослід, викладач пропонує студентам зробити висновки. Проблемні ситуації виникають на всіх структурних етапах. Наприклад, під час проведення фронтальної бесіди, використовуючи проблемні запитання, або під час перевірки стану засвоєння матеріалу, узагальнення та систематизації знань студентів. Тому ця форма має багато можливостей для практичного використання.

Особливістю проблемного навчання є також те, що воно змінює мотивацію пізнавальної діяльності студентів: провідними стають пізнавально-спонукальні (інтелектуальні) мотиви. Інтерес до навчання виникає у зв'язку з проблемою і розгортається у процесі розумової праці, пов'язаної з пошуками та знаходженням рішення проблемного завдання або сукупності завдань. На цих засадах виникає внутрішня зацікавленість, що перетворюється у чинник активізації навчального процесу та ефективності навчання. Пізнавальна мотивація спонукає людину розвивати свої схильності та можливості [6].

Як відомо, у професійній діяльності лікаря важливу роль відіграє вміння правильно діагносту- 
вати захворювання. У сучасних умовах медична діагностика і зокрема медична радіологія [5] $€$ конгломератом фундаментальних наук, сучасних методів обстеження та інформаційно-комунікаційних технологій. 3 огляду на те, що в основі більшості діагностичних радіологічних методів лежать фізичні закони, теорії, наукові факти, а також фізичні властивості об’ єктів [1] і закономірності перебігу фізичних явищ, не викликає сумніву необхідність навчати майбутнього лікаря діагностичної діяльності не тільки при вивченні фахових дисциплін, але й уже на етапі вивчення медичної фізики [7]. У цьому аспекті застосовуємо компетентнісний підхід, у рамках якого закладаються основи діагностичних компетенцій майбутніх фахівців з медицини.

Висновки та перспективи подальших досліджень. Таким чином, методи та підходи щодо інновації освітнього процесу, які вже реалізовані на кафедрі медичної фізики діагностичного та ліку-

\section{Список літератури}

1. Галайчук I. Й. Неінвазивні методи діагностики меланоми шкіри / І. Й. Галайчук, О. С. Гоцко, І. В. Жулкевич // Вісник наукових досліджень. - 2015. - № 1. - С. 67-70.

2. Гур'янова О. В. Активізація творчого мислення студентів за допомогою нових педагогічних технологій / О.В.Гур’янова // Наукові записки КДПУ. Серія: Педагогічні науки / ред. кол. : В. В. Радул [та ін.]. - Кіровоград : КДПУ ім. В. Винниченка, 2013. - Вип. 120. - С. 117-127.

3. Дубасенюк О. А. Інноваційні навчальні технологіїоснова модернізації університетської освіти / О.А.Дубасенюк // Освітні інноваційні технології у процесі викладання навчальних дисциплін : зб. наук.-метод. праць / за ред. О. А. Дубасенюк. - Житомир : Вид-во ЖДУ, 2004. - С. 3-14.

4. Медична і біологічна фізика / [О.В.Чалий, Б. Т. Агапов, Я. В. Цехмістер та ін.] ; за заг. ред. О. В. Чалого. К. : Книга плюс, 2005. - 760 с.

5. Новітні впровадження в педагогічний процес викладання радіології на третьому курсі медичного факультету / І. В. Жулкевич, І. М. Леськів, І. Й. Галайчук, Н. О. Загурська // Медична освіта. - 2014. - № 1. - С. 64- 66.

6. Педагогіка вищої школи : навч. посіб. / [3. Н. Курлянд, Р. І. Хмелюк, А. В. Семенова та ін.]. - К. : Знання, 2005. - 399 с.

7. Розробка проблеми остеопорозу: приклад інтеграції планової наукової роботи кафедри та навчального про-

\section{References}

1. Halaichuk, I.Y., Hotsko, O.S., \& Zhulkevych, I.V. (2015). Neinvazyvni metody diahnostyky melanomy shkiry [Non-invasive methods for the diagnosis of skin melanoma]. Visnyk naukovykh doslidzhen - Bulletin of Scientific Researches, 1, 67-70 [in Ukrainian]. вального обладнання Тернопільського національного медичного університету, покращують засвоюваність знань та сприяють підвищенню інтересу у студентів до вивчення медичної та біологічної фізики.

Попри впровадження нових технологій і підходів у викладання медичної фізики, не втрачає актуальності проблема побудови логічної структури змісту предмета, встановлення міжпредметних і внутрішніх зв’язків фізики та суміжних предметів, наскрізних знань на основі системного підходу і технології структурно-логічного аналізу тощо. Це дозволить реалізувати принцип наочності змісту і структури теми, розділу, курсу, забезпечити систематичне вивчення як змістових, так і світоглядних понять, перехід від емпіричного до науково-теоретичного способу.

Шляхи вирішення цих проблем будуть розглянуті нами у подальших дослідженнях.

цесу / С. І. Сміян, О. М. Масик, О. Й. Бакалюк, І. В. Жулкевич // Нові технології навчання в медичному вищому навчальному закладі : матеріали навч.-метод. конф. Тернопіль : Укрмедкнига, 2000. - С. 156-159.

8. Сазоненко Г. С. Інноваційна культура освіти / Г. С. Сазоненко // Управління освітою. - 2010. - № 1318. - C. 6-10.

9. Стадніченко С. М. Формування природничо-наукового мислення у студентів вищих медичних навчальних закладів у вивченні фізики / С. М. Стадніченко // Наукові записки НДУ ім. М. Гоголя. Психолого-педагогічні науки. - 2011. - № 10. - С. 173-176.

10. Стучинська Н. В. Роль та місце фундаментальних дисциплін у системі вищої медичної освіти / Н. В. Стучинська // Наукові записки : зб. наук. праць Кам’янецьПодільського державного педагогічного університету. Серія педагогічна : Дидактика дисциплін фізико-математичної та технологічної освітніх галузей. - К.-Под. : Кам'янець-Подільський держ. ун-т, 2002. - Вип. 8. C. 319-324.

11. Fischer R. Problemorientiertes Lernen in Theorie und Praxis. Leitfaden für Gesundheitsberufe / R. Fischer. - Stuttgart, 2004. - $326 \mathrm{p}$.

12. Weber A. Problem Based Learning. Ein Handbuch für die Ausbildungauf der Sekundarstufe II und Tertiärstufe / A. Weber. - Bern, 2007. - 193 p.

2. Hurianova, O.V. (2013). Aktyvizatsiia tvorchoho myslennia studentiv za dopomohoiu novykh pedahohichnykh tekhnolohii [Activation of students' creative thinking with the help of new pedagogical technologies]. Naukovi zapysky KDPU. Seriia: Pedahohichni nauky - 
KSPU Scientific Notes. Series: Pedagogical Sciences, 120, 117-127 [in Ukrainian].

3. Dubaseniuk, O.A. (Ed.). (2004). Innovatsiini navchalni tekhnolohii - osnova modernizatsii universytetskoi osvity [Innovative teaching technologies are the basis for the modernization of university education]. Osvitni innovatsiini tekhnolohii u protsesi vykladannia navchalnykh dystsyplin: $\mathrm{Zb}$. nauk.-metod prats. - Educational Innovative Technologies in the Course of Teaching Subjects: Collection of Scientific and Methodical Works. Zhytomyr: Vyd-vo ZhDU [in Ukrainian].

4. Chalyi, O.V., Ahapov, B.T., Tsekhmister, Ya.V., Chalyi, K.O., Stuchynska, N.V., Melenevska, A.B., ..., \& Radchenko, N.F. (2005). Medychna i biolohichna fizyka [Medical and Biological Physics]. Kyiv: Knyha plius [in Ukrainian].

5. Zhulkevych, I.V., Leskiv, I.M., Halaychuk, I.Y., \& Zahurska, N.O. (2014). Novitni vprovadzhennia v pedahohichnyi protses vykladannia radiolohii na tretiomu kursi medychnoho fakultetu [The newest introductions to the pedagogical process of teaching Radiology in the third year of the medical faculty]. Medychna osvita-Medical Education, 1, 64-66 [in Ukrainian].

6. Kurliand, Z.N., Khmeliuk, R.I., Semenova, A.V., Barteneva, I.O., Bohdanova, I.M., \& Vuzhyna, I.V. (2002). Pedahohika vyshchoi shkoly: navch. posib. [Tertiary education: Manual]. Kyiv: Znannia [in Ukrainian].

7. Smiian, S.I., Masyk, O.M., Bakaliuk, O.Y., \& Zhulkevych, I.V. (2000). Rozrobka problemy osteoporozu: pryklad intehratsii planovoi naukovoi roboty kafedry ta navchalnoho protsesu [Development of the problem of osteoporosis: an example of the integration of planned scientific work of the department and the educational process]. Materials of educational methodological conference: “Novi tekhnolohii navchannia $v$ medychnomu vyshchomu navchalnomu zakladi" - "New Teaching Technologies in Medical Higher Education”. Ternopil: Ukrmedknyha (pp. 156-159) [in Ukrainian].

8. Sazonenko, H.S. (2010). Innovatsiina kultura osvity [Innovative education culture]. Upravlinnia osvitoiu -Management of Education, 13-18, 6-10 [in Ukrainian].

9. Stadnichenko, S.M. (2011). Formuvannia pryrodnychonaukovoho myslennia u studentiv vyshchykh medychnykh navchalnykh zakladiv u vyvchenni fizyky [Formation of Natural Science thinking in students of medical schools in the learning Physics]. Naukovi zapysky NDU im. M. Hoholia. Psykholoho-pedahohichni nauky - Scientific Notes of M. Hohol NSU. Psychological and Pedagogical Sciences, 10, 173-176 [in Ukrainian].

10. Stuchynska, N.V. (2002). Rol ta mistse fundamentalnykh dystsyplin u systemi vyshchoi medychnoi osvity [Role and place of fundamental disciplines in the higher medical education system]. Naukovi zapysky: $Z$ b. naukovykh prats Kamianets-Podilskoho derzhavnoho pedahohichnoho universytetu: Seriia pedahohichna: Dydaktyka dystsyplin fizyko-matematychnoi ta tekhnolohichnoi osvitnikh haluzei - Scientific Notes: Collection of Scientific Works of Kamianets-Podilskyi State Pedagogical University: Pedagogical Series: Didactics of Physical, Mathematical and Technological Educational Subjects, 8, 319-324 [in Ukrainian].

11. Fischer, R. (2004). Problemorientiertes Lernen in Theorie und Praxis. Leitfaden für Gesundheitsberufe. Stuttgart.

12. Weber, A. (2007). Problem based learning. Ein Handbuch für die Ausbildungauf der Sekundarstufe II und Tertiärstufe. Bern.

Електронна адреса для листування: palasyukbm@tdmu.edu.ua 